\title{
Huge Dose Vitamin B12 (Vit B12) Treatment for Pernicious Anemia
}

\section{Pernisiöz Anemide Çok Yüksek Doz Vitamin B12 Tedavisi}

\author{
Şinasi Özsoylu \\ Fatih University School of Medicine, Department of Hematology, Ankara, Turkey
}

\section{To the Editor,}

The recent letter by Aytaç and colleagues, entitled "Poland syndrome associated with pernicious anemia and gastric dysplasia", gives me an opportunity to question the vitamin B12 dose administered for the treatment of pernicious anemia [1].

Vitamin B12 was initiated by the authors (1000 $\mu$ g daily for 5 days, $1000 \mu \mathrm{g}$ weekly for 4 weeks, and then $1000 \mu \mathrm{g}$ monthly for life) without taking into account that its daily requirement is $2 \mu \mathrm{g}$ and its half-life is more than 350 days $[2,3,4,5]$.

Although to my knowledge, vitamin B12 toxicity has not been reported, its extra benefit related to huge doses is also not known.

On this occasion, I would like to bring to attention that the Poland syndrome's association with leukemia was previously reported by us [6].

\section{References}

1. Aytaç E, Durgun AV, Büyüktaş D, Erdamar S, Ongören S. Poland Syndrome Associated with Pernicious Anemia and Gastric Dysplasia Turk J Hematol 2012;29:441-444

2. Irken G, Özsoylu S, Yetgin S, Gurgey A et al. Çocukluk çağında vit B12 eksikliğine bağlı megalo blastik anemi. Çocuk Sag ve Hast. Dergisi 1989;32:29-37.

3. Özsoylu Ş. Gastrointestinal bulgularla giden bir konjenital Vitamin B12 eksikliği vakası. Çocuk Sağ ve Hast Der 2008;51:74-9.

4. Ozsoylu S. Vitamin B12 (vit B12) deficiency treatment in infants and its prevention. Turk J Pediatric 2011;53:718.
5. Özsoylu Ş. Vit B12 treatment. Eur J Pediatr 2012;171:737.

6. Hiçsönmez G, Özsoylu Ş. Poland syndrome and leukemia. Am J Dis Children 1982;136:1098-9.

\section{Authors' reply: B-12 Regimen for Treatment of Pernicious Anemia}

It has been a great honor for us to have a chance to criticize the debatable topic with Professor Özsoylu, we appreciate his kind interest to our case presentation and also giving us the opportunity to comment on this issue. The management strategy of the adult patient in our report was planned by considering existing B-12 deficiency and the operation performed subsequently, a total gastrectomy. Although daily requirement and in-vivo metabolism of B-12 is known, some of the expert hematologists treat pernicious anemia with high dose B-12 in current clinical practice $[1,2]$. They also claim that beginning with high dose B-12 replacement helps delay relapse especially in patients who may discontinue treatment [1]. While there are various recommended schedules for vitamin B12 injections, there is no consensus on an exact B-12 regimen for pernicious anemia [2]. As Professor Özsoylu stated, new studies questioning B-12 regimen for pernicious anemia are needed.

\section{Erman Aytac, Deram Buyuktas}

\section{References}

1. Carmel R. How I treat cobalamin (vitamin B12) deficiency. Blood 2008;112:2214-2221.

2. Stabler SP. Clinical practice. Vitamin B12 deficiency. N Engl J Med 2013;368:149-160.

Address for Correspondence: Şinasi ÖZSOYLU, M.D.,

Fatih University, School of Medicine, Department of Hematology, Ankara, Turkey

Phone: +90 3122354188 E-mail: sinasiozsoylu@hotmail.com

Received/Geliş tarihi : February 17, 2013

Accepted/Kabul tarihi : February 18, 2013 